\title{
Potential of Prebiotics and Probiotics to Enhance the Efficacy of HIV Vaccination: A Hypothesis
}

Rastmanesh $\mathbf{R}^{1}$ and F Marotta ${ }^{2 *}$

${ }^{1}$ Shahid Beheshti University of Medical Sciences, National Nutrition and Food Technology Research Institute, Tehran, Iran ${ }^{2}$ ReGenera Research Group for Aging Intervention, Milano, Italy

Globally, acquired immunodeficiency syndrome (AIDS) is an epidemic, severe and fatal disease. Extensive research to develop a vaccine for AIDS has been undertaken. Heat shock proteins (HSP), a class of functionally related proteins whose expression is increased when cells are exposed to elevated temperatures or other stress [1] of different origins, with molecular weights of about 60,70 , and $90 \mathrm{kDa}$, play a pivotal role in viral infections, including human immunodeficiency virus (HIV) [2]. HSP70 plays an important role in the life cycle of HIV1 virus [3] and is over expressed in HIV-infected cells, and this is the most abundant HSP associated with HIV virions [4]. HIV-infection induces a marked increase in the anti-HSP70 antibody levels [4,5], which is consistent with the enhanced expression of HSP70 on the surface of HIV-infected cells and/or incorporation of the protein into the membrane of HIV virions; highly active antiretroviral therapy leads to normalization of the levels of anti-HSP70 [5]. It is promising that prebiotics/and or probiotics can enhance HSPs which are important in HIV patients, such as HSP70. Probiotics/and or prebiotics have been examined for their effectiveness in the prevention and treatment of a diverse spectrum of disorders, however, there is currently no clinical trial investigating their effectiveness in HIV vaccination. More knowledge about the interplay between the innate and adaptive immune responses, and nutrient-induced modulation in HSP levels is important to develop new HIV vaccine strategies. It has been shown that nutrients and dietary interventions can modulate HSP levels in animals [6-17] and in humans [18]. In this paper, we overview some evidence regarding potential beneficial effects of such prebiotic and /or probiotic dietary supplementation in connection with HIV vaccines. Implications of this hypothesis cover other similar situations.

HSP binding to viral complexes can enhance antiviral immunity, including natural killer, antibody-dependent, gamma delta T-cell and cytotoxic T-lymphocyte activities against HIV-1 infected cells $[19,20]$. On the other hand, there are reports of enhanced HSP70 expression following a dairy strain of Lactobacillus helveticus MIMLh5 supplementation in FaDu cells in the human pharynx [21], Escherichia coli Nissle in gastric cells in rats [22], in enterocyte-like Caco-2 cells after exposure to non-starter lactobacilli [23], enhanced HSP27 followed by Bacillus subtilis supplementation in humans [24]. Furthermore, prebiotics have been shown to overexpress HSP25 in colonic mucosa in rats [25].

Another novel and important finding from a recent study was that the levels of some key regulatory proteins were elevated in Caco2 cells in response to contact with Lactobacillus fermentum I5007. They include spectrin-a, major vault protein, voltage-dependent anion channel-1, glutathione transferase, and HSP gp96. HSP gp96 (an endoplasmic reticulum protein) and they are different from other HSP proteins and they play an important role in the immune response [26]. It should be reminded that strong CD4+ and CD8+ $\mathrm{T}$ cell responses are considered important immune components for controlling HIV infection and their priming may be central to an effective HIV vaccine. Goulder and colleagues described an approach by which multiple CD4+and CD8+ T cell epitopes are processed and presented from an exogenously added HIV-1 Gag-p24 peptide of 32 a complexed to HSP gp96. CD8+ T cell recognition of the HSP/peptide complex, but not the peptide alone, was inhibited by brefeldin A, suggesting an endoplasmic reticulum-dependent pathway. Their study is the first report to describe an efficient processing and simultaneous presentation of overlapping class I- and class II-restricted epitopes from the same extracellularly added precursor peptide complexed to HSP. Their data suggested that HSP-complexed peptides containing multiple MHC class I- and class II-restricted epitopes represent potential vaccine candidates for HIV and other viral infections suitable to induce effective CTL memory by simultaneously providing CD4 T cell help [3].

Currently, one HSP, the endoplasmic reticulum stress-response protein Gp96 is undergoing clinical trials for cancer treatment and has yielded promising results, including the induction of anti-tumor immunity and some benefit for patients when administered as part of a multi dose regimen.

We hypothesize that artificial over-expression of HSPs might enhance efficacy of HIV vaccination in humans. There is only one case report of a patient who developed bacteraemia and septic pulmonary emboli with Lactobacillus acidophilus after taking a probiotic containing this organism [27], however, S. boulardii has been used to treat $33 \mathrm{HIV}$ patients with chronic diarrhea. In these doubleblind studies, $56 \%$ of patients receiving S. boulardii had resolution of diarrhea compared with only $9 \%$ of patients receiving placebo. There were no case of bacteraemia and septic pulmonary emboli in either study $[28,29]$. Overall, such studies will also give encouragement to industries to think about possibility of pre/ pro biotic formulations for a higher efficacy of HIV vaccination, worldwide.

At present, there are not sufficient published works to perform a comprehensive review. Nevertheless we encourage researchers to consider this interesting topic, while making subsections to HSPs, pre /pro biotics and viral infections. We hypothesize that different pre / probiotics might influence different HSPs differently and therefore viral infections, consequently.

Also, it will be helpful to address the questions whether pre/ probiotics elevate HSPs by involving HSF-1, whether such an increase is a result of stress, and how do elevated intracellular levels of HSPs

*Corresponding author: Francesco Marotta, ReGenera Research Group for Aging Intervention, Texas University, Department of Human Nutrition, Piazza Firenze, Milano, Italy, Tel: 39024077243; E-mail: fmarchimede@libero.it

Received September 15, 2011; Accepted December 03, 2011; Published December 05, 2011

Citation: Rastmanesh R, Marotta F (2012) Potential of Prebiotics and Probiotics to Enhance the Efficacy of HIV Vaccination: A Hypothesis. Metabolomics 2:108e. doi:10.4172/2153-0769.1000108e

Copyright: (c) 2012 Rastmanesh R, et al. This is an open-access article distributed under the terms of the Creative Commons Attribution License, which permits unrestricted use, distribution, and reproduction in any medium, provided the original author and source are credited. 
Citation: Rastmanesh R, Marotta F (2012) Potential of Prebiotics and Probiotics to Enhance the Efficacy of HIV Vaccination: A Hypothesis. Metabolomics 2:108e. doi:10.4172/2153-0769.1000108e

Page 2 of 2

contribute to $\mathrm{T}$ cell responses? Keep in mind, in most adaptive immune responses the HSPs have been administered exogenously. And finally, but not least important, are elevated levels of HSP good or bad for viral infection since it seems all might be true.

\section{References}

1. De Maio A (1999) Heat shock proteins: facts, thoughts, and dreams. Shock 11 $1-12$.

2. Multhoff $\mathrm{G}$ (2006) Heat shock proteins in immunity. Handb Exp Pharmacol 279304

3. SenGupta D, Norris PJ, Suscovich TJ, Hassan-Zahraee M, Moffett HF, et al (2004) Heat shock protein-mediated cross-presentation of exogenous HIV antigen on HLA class I and class II. J Immunol 1: 1987-1993.

4. Kocsis J, Prohaszka Z, Biro A, Fust G, Banhegyi D (2003) Elevated levels of antibodies against $70 \mathrm{kDa}$ heat shock proteins in the sera of patients with HIV infection. J Med Virol 71: 480-482.

5. Fust G, Beck Z, Banhegyi D, Kocsis J, Biro A, et al. (2005) Antibodies against heat shock proteins and cholesterol in HIV infection. Mol Immunol. 42: 79-85.

6. Xue H, Sawyer MB, Field CJ, Dieleman LA, Murray D, et al. (2008) Bolus ora glutamine protects rats against CPT-11-induced diarrhea and differentially activates cytoprotective mechanisms in host intestine but not tumor. J Nutr 138 : 740-746.

7. Wischmeyer PE (2002) Glutamine and heat shock protein expression. Nutrition 18: $225-228$.

8. Sharma S, Kaur G (2005) Neuroprotective potential of dietary restriction against kainate-induced excitotoxicity in adult male Wistar rats. Brain Res Bull 67: 482-491

9. Sharma S, Kaur G (2007) Intermittent dietary restriction as a practical intervention in aging. Ann NY Acad Sci 1114: 419-427.

10. Selsby JT, Judge AR, Yimlamai T, Leeuwenburgh C, Dodd SL (2005) Life long calorie restriction increases heat shock proteins and proteasome activity in soleus muscles of Fisher 344 rats. Exp Gerontol 40: 37-42.

11. Rosier OPI, Saes PAD (2006) Soy isoflavones reduce heat shock proteins in experimental atherosclerosis. Eur J Nutr 45: 178-186.

12. Oksala NK, Laaksonen DE, Lappalainen J, Khanna S, Nakao C, et al. (2006) Heat shock protein 60 response to exercise in diabetes: effects of alpha-lipoic acid supplementation. J Diabetes Complications 20: 257-261.

13. Kanazawa M, Xue CY, Kageyama H, Suzuki E, Ito R, et al. Effects of a highsucrose diet on body weight, plasma triglycerides, and stress tolerance. Nutr Rev 61: S27-S33.

14. Ghayour-Mobarhan M, Lamb DJ, Tavallaie S, Ferns GA (2007) Relationship between plasma cholesterol, von Willebrand factor concentrations, extent of atherosclerosis and antibody titres to heat shock proteins-60, -65 and -70 in cholesterol-fed rabbits. Int J Exp Pathol 88: 249-255.
15. Frier B, Locke M (2005) Preservation of heat stress induced myocardial hsp 72 in aged animals following caloric restriction. Exp Gerontol 40: 615-617.

16. Figueiredo D, Gertler A, Cabello G, Decuypere E, Buyse J, et al. (2007) Leptin downregulates heat shock protein-70 (HSP-70) gene expression in chicken liver and hypothalamus. Cell Tissue Res 329: 91-101.

17. Bornman L, Rossouw H, Gericke GS, Polla BS (1998) Effects of iron deprivation on the pathology and stress protein expression in murine $\mathrm{X}$-linked muscula dystrophy. Biochem Pharmacol 56: 751-757.

18. Ziegler TR, Ogden LG, Singleton KD, Luo M, Fernandez-Estivariz C, et al (2005) Parenteral glutamine increases serum heat shock protein 70 in critically ill patients. Intensive Care Med 31: 1079-1086.

19. Brenner BG, Wainberg MA (1999) Heat shock protein-based therapeutic strategies against human immunodeficiency virus type 1 infection. Infect Dis Obstet Gynecol 7: 80-90

20. Brenner BG, Wainberg $Z$ (2001) Heat shock proteins: novel therapeutic tools for HIV-infection? Expert Opin Biol Ther 1: 67-77.

21. Guglielmetti S, Taverniti V, Minuzzo M, Arioli S, Zanoni I, et al. (2010) A dairy bacterium displays in vitro probiotic properties for the pharyngeal mucosa by antagonizing group A streptococci and modulating the immune response. Infect Immun 78: 4734-4743.

22. Konturek PC, Sliwowski Z, Koziel J, Ptak-Belowska A, Burnat G, et al. (2009) Probiotic bacteria Escherichia coli strain Nissle 1917 attenuates acute gastric lesions induced by stress. J Physiol Pharmacol 60 Suppl 6: 41-48.

23. Nemeth E, Fajdiga S, Malago J, Koninkx J, Tooten P, et al. (2006) Inhibition of Salmonella-induced IL-8 synthesis and expression of Hsp70 in enterocyte-like Caco-2 cells after exposure to non-starter lactobacilli. Int J Food Microbiol 112 266-274.

24. Williams $P$ (2007) Bacillus subtilis: a shocking message from a probiotic. Cell Host Microbe 1: 248-249.

25. Kanauchi O, Mitsuyama K, Andoh A, Iwanaga T (2008) Modulation of intestina environment by prebiotic germinated barley foodstuff prevents chemo-induced colonic carcinogenesis in rats. Oncol Rep 20: 793-801.

26. Srivastava PK, Udono H, Blachere NE, Li Z (1994) Heat shock proteins transfe peptides during antigen processing and CTL priming. Immunogenetics 39: 93 98.

27. Ledoux D, Labombardi VJ, Karter D (2006) Lactobacillus acidophilus bacteraemia after use of a probiotic in a patient with AIDS and Hodgkin's disease. Int J STD AIDS 17: 280-282.

28. Born P, Lersch C, Zimmerhackl B, Classen M (1993) The Saccharomyces boulardii therapy of HIV-associated diarrhea]. Dtsch Med Wochenschr 118 765.

29. Saint-Marc T, Rossello-Prats L, Touraine JL (1991) Efficacy of Saccharomyces boulardii in the treatment of diarrhea in AIDS. Ann Med Interne (Paris) 142: 6465. 